University of Nebraska - Lincoln

DigitalCommons@University of Nebraska - Lincoln

\title{
Evaluation of Condensed Algal Residue Solubles as an Ingredient in Cattle Finishing Diets
}

John C. Gibbons

Bradley M. Boyd

Levi McPhillips

Andrea K. Watson

Galen E. Erickson

Follow this and additional works at: https://digitalcommons.unl.edu/animalscinbcr

Part of the Large or Food Animal and Equine Medicine Commons, Meat Science Commons, and the Veterinary Preventive Medicine, Epidemiology, and Public Health Commons

This Article is brought to you for free and open access by the Animal Science Department at DigitalCommons@University of Nebraska - Lincoln. It has been accepted for inclusion in Nebraska Beef Cattle Reports by an authorized administrator of DigitalCommons@University of Nebraska - Lincoln. 


\section{Evaluation of Condensed Algal Residue Solubles as an Ingredient in Cattle Finishing Diets}

\author{
John C. Gibbons \\ Bradley M. Boyd \\ Levi J. McPhillips \\ Andrea K. Watson \\ Galen E. Erickson
}

\section{Summary with Implications}

A study was conducted to evaluate feeding 0, 2.5, or 5.0\% of a novel liquid feed, Condensed Algal Residue Solubles (CARS), in one of two base diets with CARS replacing corn. The two base diets were fed to mimic Northern Great Plains (high moisture and dry rolled corn blend fed with wet distillers grains plus solubles) and Southern Great Plains (steam-flaked corn and dry distillers grains plus solubles) feedlot diets. There were no interactions between base diet and CARS inclusion. Feed intake and longissimus muscle area decreased as CARS inclusion increased in the diet. A quadratic effect was shown for average daily gain, feed efficiency, final adjusted body weight, hot carcass weight, $12^{\text {th }}$ rib fat, and yield grade, increasing as CARS was included up to $2.5 \%$ of diet dry matter, then decreased at 5\% inclusion. Marbling score improved with increased inclusion of CARS, with the highest score at 5\% CARS inclusion. Including CARS at $2.5 \%$ of diet dry matter improved feed efficiency in both Northern and Southern Great Plains diets.

\section{Introduction}

Mass production of algae to harvest eicosapentaenoic acid (EPA) and docosahexaenoic acid (DHA) Omega-3 fatty acids involves growing algae with sugars, then processing the cells to separate and remove the oil for the Omega-3 supplements as feed for pets and aquaculture. The liquid biproduct from this process is known as Condensed Algal Residue Solubles (CARS; 25.4\% DM, 19.3\% CP, 8.3\% Fat, 9.96\% Na on DM basis; Table 1), made up of the de-

(c) The Board Regents of the University of Nebraska. All rights reserved. oiled algae cells and residual fermentation substrates. In a previous study, CARS was included up to $7.5 \%$ of diet DM and had no adverse effect on cattle with improved performance when fed up to $5.0 \%$ of diet DM (2019 Nebraska Beef Cattle Report, pp. 82-84). From this previous study, CARS was granted GRAS (generally recognized as safe) status and has become commercially available (Veramaris, Blair, NE). The objective of this study was to determine the feeding value of CARS in feedlot finishing diets that represent Northern and Southern Great Plains finishing diets.

\section{Procedure}

Crossbreed steers $(\mathrm{n}=480$; initial $\mathrm{BW}=$ $951 \mathrm{lb}$; SD $84 \mathrm{lb}$ ) were blocked and stratified by initial BW into 4 blocks and assigned randomly to pens $(n=48)$ after the first day of weight collections. Pens were assigned randomly to treatment. Treatments were designed as a $2 \times 3$ factorial with 3 inclusions of CARS $(0,2.5,5 \%$ of diet DM) in 2 base diets representing Northern and Southern Great Plains diets (Table 2). All diets included a $4 \%$ dry meal supplement containing Rumensin-90 (fed to target $30 \mathrm{~g} /$ ton of diet DM, Elanco Animal Health) and Tylan-40 (fed to target $90 \mathrm{mg} / \mathrm{hd} / \mathrm{d}$, Elanco Animal Health), along with trace minerals, vitamins $\mathrm{ADE}$, tallow, calcium, salt (not included in the 5\% CARS diets) and $0.5 \%$ urea to ensure RDP requirements were met. Diets were formulated to provide similar $\mathrm{Ca}$ and appropriate $\mathrm{Ca}: \mathrm{P}$ ratios. Southern diets contained steam flaked corn (SFC) and $15 \%$ dry distillers grains (DDGS) while the Northern diets contained dry rolled (DRC) and high moisture corn (HMC) with 15\% wet distillers grains (WDGS). The CARS feed is a liquid and replaced either DRC/ HMC or SFC in the diets.

All steers were limit fed at $2 \%$ of body weight for 5 days prior to the start of the trial using 50\% alfalfa and 50\% Sweet Bran (Cargill, Blair, NE) as a common diet to minimize differences in gut fill. Steers were
Table 1. Nutrient composition of CARS and FAME analysis (DM basis)

\begin{tabular}{|c|c|}
\hline Item & CARS $^{1}$ \\
\hline Dry Matter (DM), \% & 25.43 \\
\hline \multicolumn{2}{|c|}{ Dry Basis } \\
\hline Crude Protein & 19.30 \\
\hline Fat (Oil) & 15.05 \\
\hline DHA & 6.25 \\
\hline EPA & 1.98 \\
\hline Calcium & 0.44 \\
\hline Magnesium & 0.45 \\
\hline Phosphorus & 0.53 \\
\hline Potassium & 0.80 \\
\hline Sulfur & 3.05 \\
\hline Sodium & 9.96 \\
\hline \multicolumn{2}{|c|}{ ppm, DM Basis } \\
\hline Zinc & 55.4 \\
\hline Iron & 168 \\
\hline Manganese & 13 \\
\hline Copper & 8.2 \\
\hline Molybdenum & 1.18 \\
\hline $\begin{array}{l}\text { Nutrient Composition of } \\
\text { Laboratories, Inc. (Kearne }\end{array}$ & yzed by War \\
\hline
\end{tabular}

then weighed on two consecutive days before feeding to calculate average initial weight. Steers were implanted on d 1 with Revalor-IS ( $80 \mathrm{mg}$ trenbolone acetate and 16 mg estradiol, Merck Animal Health) and on d 70 were re-implanted with Revalor-200 (200 mg trenbolone acetate and 20 mg estradiol, Merck Animal Health). On d 120 to d 148 Optaflexx (Elanco Animal Health) was included in the diet at $300 \mathrm{mg} /$ hd daily. Feed refusals were collected as needed throughout the trial and analyzed for DM in order to adjust feed offered to actual dry matter intake (DMI).

All blocks were harvested after 148 days on feed. Hot carcass weight (HCW), liver abscess scores, and kill order were recorded. Carcass adjusted final body weights (BW) were calculated from HCW and a common $63 \%$ dressing percentage. Carcass adjusted 
Table 2. Dietary treatment compositions (DM basis) for finishing steers fed increasing inclusion of CARS in Northern or Southern Great Plains based diets

\begin{tabular}{|c|c|c|c|c|c|c|}
\hline \multirow[b]{2}{*}{ Ingredient, \% diet DM } & \multicolumn{3}{|c|}{ Northern } & \multicolumn{3}{|c|}{ Southern } \\
\hline & $0 \%$ & $2.5 \%$ & $5 \%$ & $0 \%$ & $2.5 \%$ & $5 \%$ \\
\hline Dry Rolled Corn & 36.5 & 35.25 & 34 & - & - & - \\
\hline High Moisture Corn & 36.5 & 35.25 & 34 & - & - & - \\
\hline Wet Distillers Grains & 15 & 15 & 15 & - & - & - \\
\hline Steam Flaked Corn & - & - & - & 73 & 70.5 & 68 \\
\hline Dried Distillers Grains & - & - & - & 15 & 15 & 15 \\
\hline CARS & 0 & 2.5 & 5 & 0 & 2.5 & 5 \\
\hline Alfalfa Haylage & 8 & 8 & 8 & 8 & 8 & 8 \\
\hline Supplement ${ }^{1}$ & 4 & 4 & 4 & 4 & 4 & 4 \\
\hline
\end{tabular}

Rumensin fed at $30 \mathrm{~g} / \mathrm{ton}(\mathrm{DM})$; Tylan fed to target $90 \mathrm{mg} / \mathrm{hd} / \mathrm{d}$

final body weight was used to calculate average daily gain (ADG) and feed to gain (F:G). Dietary NEm and NEg values were calculated utilizing initial BW, adjusted final BW, BW at target endpoint (heaviest pen average BW by block), ADG and DMI. Carcass characteristics including marbling score, 12th rib back fat thickness, longissimus muscle (LM) area, and yield grade were recorded after a 48 hour chill.

Economic analysis of CARS, as feed cost of gain, was modeled with the assumptions that CARS was equal to the cost of corn, and Northern Great Plains and Southern Great Plains base diet costs were averaged together. Corn costs used were $\$ 3.00, \$ 3.50$, $\$ 4.00$, and $\$ 4.50 /$ bushel with equivalent costs at $\$ 0.06, \$ 0.07, \$ 0.08, \$ 0.10 / \mathrm{lb}$ of DM. Results of this analysis are reported as feed cost of gain/cwt body weight gained.

Performance data were analyzed using the PROC MIXED procedure of SAS (SAS institute, Inc., Cary, N.C.) as a $2 \times 3$ factorial. CARS inclusion, base diet, the interaction between CARS and base diet, and body weight block were included as fixed effects. Pen was the experimental unit. Orthogonal contrasts were used to test linear and quadratic effects of CARS inclusion. If no interaction was detected, the main effects of CARS inclusion and base diet were evaluated and are presented.

\section{Results}

One steer died from bloat during the study and two others were removed (i.e. dislocated shoulder, heart and liver issues) There were no significant interactions between CARS inclusion and diet type ( $P$ $\geq 0.49$ ) for any variable tested. Therefore, main effects are discussed.

\section{CARS inclusion main effects}

Increasing inclusion of CARS resulted in a linear decrease $(P<0.01)$ in DMI. There was a positive quadratic response for ADG $(P<0.01)$, with $0 \%$ and $2.5 \%$ CARS having similar ADG and decreasing at the 5\% CARS inclusion. This resulted in a quadratic response for F:G $(P<0.01)$ as CARS inclusion in the diet increased with 2.5\% CARS inclusion having the lowest F:G with a $4.3 \%$ improvement compared to the control and 5\% CARS treatment having the greatest F:G. There was a positive quadratic response for both NEm and NEg $(P<$ 0.01 ), with $0 \%$ and $5 \%$ CARS having similar values and 2.5\% CARS having the greatest value. Both carcass adjusted final BW and HCW had positive quadratic responses $(P$ $<0.01)$ as CARS inclusion increased in the diet, with final body weights and HCW being the heaviest at the $2.5 \%$ inclusion level. Longissimus muscle area linearly decreased $(P<0.01)$ with increasing inclusion of CARS. Measures of $12^{\text {th }}$ rib fat thickness showed a positive quadratic response $(P$ $<0.01$ ) with maximum $12^{\text {th }}$ rib fat at $2.5 \%$ CARS inclusion and $5 \%$ CARS having the least. Marbling score linearly increased $(P$ $<0.01$ ) from 563 with $0 \%$ CARS to 598 with $5 \%$ CARS, but all treatments averaged choice grade. Yield grade had a positive quadratic response $(P<0.01)$, with a maximum yield grade observed at the $2.5 \%$ CARS inclusion, while $0 \%$ and $5 \%$ CARS inclusion had similar grades.

\section{Main effects of diet}

Main effects of diet indicated that DMI for both Northern and Southern Plains were similar $(P=0.72)$. Southern diets had greater ADG compared to Northern diets $(P<0.01)$ and $\mathrm{F}: \mathrm{G}$ was $5.9 \%$ greater for Southern compared to Northern diets $(P<$ $0.01)$. Steam-flaked corn diets commonly increase feed efficiency by $12 \%$ compared to dry rolled corn diets. The improved efficiency measured in this trial was only half that amount, likely due to differences between dry and wet distillers grains in these diets. Dietary NEm and NEg were different between base diets $(P<0.01)$, with Southern diets having greater energy concentration than Northern diets due to the SFC in the Southern diets. Steers fed the Southern diets had greater carcass adjusted final body weights and improved HCW compared to steers fed the Northern diets $(P<0.01)$. The longissimus muscle area was statistically similar for both diets $(P=$ 0.09 ) while 12th rib fat thickness and YG were greater for Southern diets compared to the Northern $(P=0.02)$. Marbling scores were not statistically different $(P=0.06)$ but Southern diets had numerically greater scores compared to the Northern diets.

\section{Economic Analysis}

Economics are reported as feed cost of gain/cwt final body weight gain. In each scenario of different corn prices there was a quadratic decrease in feed cost of gain as CARS inclusion increased in the diet $(P<0.01)$. For all scenarios, $2.5 \%$ CARS inclusion had the lowest feed cost of gain. As corn price (feed costs) increased, the average savings increased from $\$ 1.74 / \mathrm{cwt}$ for $2.5 \%$ CARS compared to $0 \%$ CARS at $\$ 3 / \mathrm{bu}$ corn up to $\$ 2.60 / \mathrm{cwt}$ at $\$ 4.50 / \mathrm{bu}$ corn cost. Similarly, the average loss incurred also increased from $\$ 0.54 / \mathrm{cwt}$ to $\$ 0.81 / \mathrm{cwt}$ for the $5 \%$ CARS treatment compared to $0 \%$ CARS as corn cost increased from $\$ 3 / \mathrm{bu}$ to $\$ 4.50$ / bu. Therefore, if CARS can be purchased, delivered, and fed for similar costs as corn, 
Table 3. Main effects of CARS inclusion on growth performance and carcass characteristics

\begin{tabular}{|c|c|c|c|c|c|c|c|}
\hline \multirow[b]{2}{*}{ Item } & \multicolumn{3}{|c|}{ Treatment $^{1}$} & \multirow[b]{2}{*}{ SEM } & \multicolumn{3}{|c|}{$P$-value ${ }^{2}$} \\
\hline & $\mathrm{CON}(0)$ & 2.5 & 5 & & CARS & Linear & Quadratic \\
\hline \multicolumn{8}{|l|}{ Performance } \\
\hline Initial BW, lb & 951 & 951 & 951 & 0.8 & 0.81 & 0.55 & 0.80 \\
\hline Final BW, $\mathrm{lb}^{3}$ & $1566^{\mathrm{a}}$ & $1576^{\mathrm{a}}$ & $1504^{\mathrm{b}}$ & 8.9 & $<0.01$ & $<0.01$ & $<0.01$ \\
\hline DMI, lb/d & $26.2^{\mathrm{a}}$ & $25.5^{b}$ & $23.9^{\mathrm{c}}$ & 0.256 & $<0.01$ & $<0.01$ & 0.05 \\
\hline $\mathrm{ADG}, \mathrm{lb}^{3}$ & $4.15^{\mathrm{a}}$ & $4.22^{\mathrm{a}}$ & $3.74^{\mathrm{b}}$ & 0.061 & $<0.01$ & $<0.01$ & $<0.01$ \\
\hline Feed to Gain & $6.32^{\mathrm{a}}$ & $6.05^{b}$ & $6.41^{\mathrm{a}}$ & 0.085 & $<0.01$ & 0.32 & $<0.01$ \\
\hline NEm, Mcal/lb & $0.89^{\mathrm{a}}$ & $0.92^{\mathrm{b}}$ & $0.89^{\mathrm{a}}$ & 0.018 & $<0.01$ & 0.66 & $<0.01$ \\
\hline NEg, Mcal/lb & $0.59^{\mathrm{a}}$ & $0.62^{\mathrm{b}}$ & $0.59^{\mathrm{a}}$ & 0.017 & $<0.01$ & 0.70 & $<0.01$ \\
\hline \multicolumn{8}{|c|}{ Carcass Characteristics } \\
\hline HCW, lb & $986^{\mathrm{a}}$ & $993^{a}$ & $948^{b}$ & 5.5 & $<0.01$ & $<0.01$ & $<0.01$ \\
\hline LM area, in ${ }^{2}$ & $15.0^{\mathrm{a}}$ & $14.8^{\mathrm{a}}$ & $14.3^{\mathrm{b}}$ & 0.16 & $<0.01$ & $<0.01$ & 0.28 \\
\hline $12^{\text {th }}$ Rib Fat, in & $0.63^{\mathrm{a}}$ & $0.67^{\mathrm{b}}$ & $0.61^{\mathrm{a}}$ & 0.016 & $<0.01$ & 0.21 & $<0.01$ \\
\hline $\begin{array}{l}\text { Marbling } \\
\text { Score }^{4}\end{array}$ & $563^{\mathrm{a}}$ & $579^{\mathrm{ab}}$ & $597^{\mathrm{b}}$ & 10.4 & $<0.01$ & $<0.01$ & 0.88 \\
\hline Yield Grade & $3.57^{\mathrm{a}}$ & $3.67^{\mathrm{b}}$ & $3.51^{\mathrm{a}}$ & 0.038 & $<0.01$ & 0.20 & $<0.01$ \\
\hline \multicolumn{8}{|c|}{ Means within a row that lack a common superscript differ $(P<0.05)$} \\
\hline \multicolumn{8}{|c|}{$\begin{array}{l}\text { Treatments were arranged as a } 2 \times 3 \text { factorial and included CARS at } 0,2.5 \text {, and } 5 \% \text { of diet DM in both Northern and Southern } \\
\text { Great Plains diets }\end{array}$} \\
\hline \multicolumn{8}{|c|}{$\begin{array}{l}\text { Main effects included CARS inclusion in the diet and diet type (Northern or Southern Great Plains). The interaction between } \\
\text { diet and CARS was not significant for any variable measured }(P \geq 0.49) \text {. Linear and quadratic orthogonal contrasts are shown } \\
\text { for CARS inclusion in the diet }\end{array}$} \\
\hline \multicolumn{8}{|c|}{${ }^{3}$ Calculated from hot carcass weight, adjusted to a common $63 \%$ dressing percentage } \\
\hline Marbling Score 400-Sma & $0,500=\mathrm{Mod}$ & & & & & & \\
\hline
\end{tabular}

Table 4. Main effects of base diets on growth performance and carcass characteristics

\begin{tabular}{|c|c|c|c|c|}
\hline \multirow[b]{2}{*}{ Item } & \multicolumn{2}{|c|}{ Treatment $^{1}$} & \multirow[b]{2}{*}{ SEM } & \multirow[b]{2}{*}{$P$-value ${ }^{2}$} \\
\hline & Northern & Southern & & \\
\hline \multicolumn{5}{|l|}{ Performance } \\
\hline Initial BW, lb & 951 & 951 & 0.8 & 0.71 \\
\hline Final BW, $\mathrm{lb}^{3}$ & 1531 & 1566 & 8.9 & $<0.01$ \\
\hline $\mathrm{DMI}, \mathrm{lb} / \mathrm{d}$ & 25.2 & 25.1 & 0.256 & 0.72 \\
\hline $\mathrm{ADG}, \mathrm{lb}^{3}$ & 3.92 & 4.16 & 0.061 & $<0.01$ \\
\hline Feed to Gain & 6.45 & 6.07 & 0.085 & $<0.01$ \\
\hline NEm, Mcal/lb & 0.88 & 0.92 & 0.008 & $<0.01$ \\
\hline NEg, Mcal/lb & 0.58 & 0.62 & 0.017 & $<0.01$ \\
\hline \multicolumn{5}{|l|}{ Carcass Characteristics } \\
\hline HCW, lb & 965 & 987 & 5.5 & $<0.01$ \\
\hline LM area, in ${ }^{2}$ & 14.6 & 14.8 & 0.16 & 0.09 \\
\hline $12^{\text {th }}$ Rib Fat, in & 0.62 & 0.65 & 0.016 & 0.02 \\
\hline Marbling Score $^{4}$ & 572 & 588 & 10.4 & 0.06 \\
\hline Yield Grade & 3.54 & 3.62 & 0.038 & 0.01 \\
\hline
\end{tabular}

${ }^{1}$ Treatments were arranged as a $2 \times 3$ factorial and included CARS at $0,2.5$, and $5 \%$ of diet DM in both Northern and Southern Great Plains diets

${ }^{2} P$-value for the main effects of base diet

${ }^{3}$ Calculated from hot carcass weight, adjusted to a common $63 \%$ dressing percentage

${ }^{4}$ Marbling Score 400-Smallo0, $500=$ Modest 00

$58 \cdot 2021$ Nebraska Beef Cattle Report small improvements in economics would be expected at the $2.5 \%$ diet inclusion.

\section{Conclusions}

Including CARS at $2.5 \%$ of diet DM improved feed efficiency and hot carcass weight compared to a $0 \%$ CARS control diet. There were no interactions between type of diet (Northern and Southern Great Plains feedlot diets) and CARS inclusion (0, 2.5 , and $5 \%$ of diet $\mathrm{DM})$. There was greater feed efficiency and hot carcass weight in Southern diets compared to the Northern base diets. Feeding 2.5\% CARS reduced feed cost of gain.

John C. Gibbons, graduate student Bradley M. Boyd, research technician Levi J. McPhillips, research technician Andrea K. Watson, research assistant professor

Galen E. Erickson, professor, Department of Animal Science, University of NebraskaLincoln 